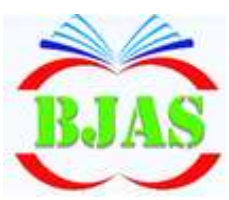

ISSN $1814-5868$
Available online at http://bjas.bajas.edu.iq

https://doi.org/10.37077/25200860.2021.34.2.05

College of Agriculture, University of Basrah

\section{Basrah Journal \\ of Agricultural Sciences \\ $\ldots, \ldots, \ldots, \ldots, \ldots$}

E-ISSN: 2520-0860

\title{
Determination of Genetic Diversity Based on RAPD molecular Marker and ParARF3 Gene Expressions in some Apricot Genotypes in Iraq
}

\author{
Ali S. A. Al-Janabi ${ }^{1 *}$ \& Arshad N. Alhasnawi2 \\ ${ }^{1}$ Department of Horticulture and Landscape Gardening, Faculty of Agriculture, University \\ of Kufa, Najaf, Iraq \\ ${ }^{2}$ Department of Biology, College of Education for Pure Sciences, Al-Muthanna University, \\ Al-Muthanna, Iraq \\ * Corresponding authors email: aljanabi@uokufa.edu.iq; ${ }^{2} \operatorname{arshad} @ \operatorname{mu} . e d u . i q$
}

Received 8th February 2021; Accepted 23 April 2021; Available online 1 November 2021

\begin{abstract}
Employing DNA markers allowed determining genetic diversity and relationships amongst five apricot genotypes. In this study, two relative gene expressions pertaining to ParARF3 gene, which could be distinguished from the genotypes that were exposed to various concentrations of marine alga treatments. As per our results, screening of seven primers with the DNA of 5 apricot genotypes was done, and six primers were generated while the primer OPN-16 gave negative results. The total quantity of fragments generated by 6 primers was 80 at an average of 13.33 fragments/primer. The highest unique percentage band depicted in U-17 touched $23 \%$, and the total number of polymorphic bands touched 17 fragments with the average reaching 2.83 fragments/primer. The number of monomorphic lied in the range of 5 to 10, with a total of 47 monomorphic. Primer M 32 yielded the highest number of monomorphic bands reaching 10. Between Zaghenia and Zinni, a maximum genetic distance value of 0.8 was reached with less similarity value of $20 \%$. A minimum genetic distance value of 0.44721 was noted between Kaisy and Baia while the high similarity value touched $55.3 \%$. According to the cluster tree analysis, the genotypes were generally split into two key groups: A and B. The Zinni group, which included one apricot genotype, showed genetic similarity of $20 \%$ with the other genotypes present in B group. The B group was split into two sub-clusters $\mathrm{B} 1$ and B2 and the genetic similarity reached 44\%. The ParARF3 relative gene expression pertaining to Zinni genotypes was second as well as convergent with that of gene expression for Zaghenia genotype results. Baia and Kaisy genotypes lied in between the lowest and highest ParARF3 value gene expression exposed to Marine Alga. These outcomes showed that RAPD markers offer an effectual alternative for the plant species genetic characterisation.
\end{abstract}

Keywords: Plant, DNA, RAPD markers, Genetic diversity, Gene expression.

\section{Introduction}

The family Rosaceae comprises few species carrying a lot of economic significance, and one of them is the genus Prunus that comprises apricot (Prunus armeniaca L.), a native to Asia (Layne et al., 1996). Prunus 
armeniaca L. is a major medicinal edible plant species generally called as "apricot". Apricot is a very delectable and globally traded fruit (Erdogan-Orhan \& Kartal, 2011). The fruit is loaded with minerals and vitamins and is frequently utilised in folk medicine for curing infertility, spasms, eye inflammation, and haemorrhages (Liu et al., 2020). The plant is enriched with mono- and polysaccharides, fatty acids, olyphenols, sterol derivatives, cyanogenic glucosides, carotenoids, and volatile constituents. It is characterised by an alluring smell. The efficacy of $P$. armeniaca has been studied for different biological activities like antimutagenic, antimicrobial, inhibitory against different enzymes, anti-inflammatory, cardioprotective, antinociceptive and antioxidant (Erdogan-Orhan \& Kartal, 2011).

Algae extract as a bio fertilizer, comprises $\mathrm{S}, \mathrm{Mg}, \mathrm{Ca}, \mathrm{K}, \mathrm{P}$, and $\mathrm{N}$; some growth regulators; $\mathrm{Co}, \mathrm{Mo}, \mathrm{Cu}, \mathrm{Mn}, \mathrm{Fe}$, and $\mathrm{Zn}$; polyamines as well as vitamins for enhancement of vegetative growth, yield, nutritional status and fruit quality; and can be used in various vineyards and orchards (Abd El-Moniem \& Abd-Allah, 2008; Spinelli et al., 2009). Seaweed extracts are produced because of the antimicrobial activity pertaining to seaweeds against yeast, bacteria, and moulds; while the influence of these extracts on cell metabolism results in increased plant growth, quality and yield via the initiation of antioxidant molecule synthesis which could enhance plant growth as well as plant resistance towards stress (Zhang \& Schmidt, 1999).

Phenotypic is an approach for determining rootstocks and genotypes on the basis of observations; however, this depends on ecological influences. Furthermore, it is a sluggish process because of the long juvenile span of trees such as apricot (Welsh et al., 1991). Unlike morphological properties, molecular markers are now being used for genetic diversity studies, as they are not impacted by environmental changes. In order to enhance the production quality of fruit, molecular markers need to be identified, which can also define the genetic make-up pertaining to the cultivars (Rowland \& Levi, 1994; Mariniello et al., 2002). A database should be created that can act as an information source regarding control of product and nursery (Koller et al., 1993; Iannelli et al., 1998).

The molecular techniques are common methods used (Kalapchieva et al., 2020; Khazraji et al., 2021). A molecular approach is ideal for certification since morphological attributes could be influenced by ecological conditions. An extensively utilised genotyping technique is random amplified polymorphic DNA (RAPD) (Sirijan et al., 2020). RAPD technique can be defined as the amplification of discrete regions pertaining to the genome by PCR containing arbitrary sequence's short oligonucleotide primers. As this methodology entails no previous knowledge of the genome which is being examined. It could be utilised for various species through universal primers. Because of their speed and efficacy, some simple methods pool together several benefits of AFLP and SSR (Wang et al., 2017).

The diversity of apricots has long been investigated in terms of morphological, pomological, and phenological attributes (Guerriero \& Watkins, 1984). Of late, DNAbased markers have been extensively utilised for clarifying the genetic relationship between the apricot accessions (Romero et al., 2003; Barakat et al., 2012; Yilmaz \& Paydas-Kargi, 2012). Lately, AFLP (Krichen et al., 2006; 
Yuan et al., 2007; Volkova et al., 2020), ISSR (Alhasnawi et al., 2017; Alhasnawi, 2019; Bhadkaria et al., 2020; Xiang et al., 2020), SSR (Maghuly et al., 2005; Chiou et al., 2020; Cmejlova et al., 2020) and SRAP (Uzuni et al., 2010; Xiang et al., 2020). Methodologies have often been utilised in apricots to portray diverse genotypes pertaining to varied ecogeographical groups. The RAPD methodology formulated by Williams et al. (1990) has been regularly utilised in apricots for evaluating genetic variability and associations between cultivars (Kumar et al., 2001; Mariniello et al., 2002).

This study intended to ascertain: genetic relationships and genetic diversity of Prunus armeniaca L. by utilising the PCR-based RAPD method; secondly, for genotypes, ParARF3 gene expressions were exposed under two concentrations of marine algae extracts (5 and $10 \mathrm{ml} . \mathrm{L}^{-1}$ ) amongst apricot genotypes (Zinni, Baia, Labeeb-1, Zaghenia and Kaisy) that were grown in Iraq.

\section{Materials \& Methods}

\section{Collection of plant material}

Leaves from five Apricot trees (Prunus armeniaca L.) genotypes (Baia, Zaghenia, Zinni, Labeeb-1 and Kaisy) were collected from Iraq's nursery of agriculture directorate in Najaf.

\section{DNA extraction from fresh leaves of apricots}

Three hundred grams of fresh apricot leaves were crushed and ground to fine powder using liquid nitrogen, then DNA was extracted according to the instructions of Genomic DNA mini Kit (Geneaid-Taiwan). Nanodrop spectrophotometer was using to measure the purity and quantity of DNA which then stored at $-20{ }^{\circ} \mathrm{C}$ until further applications.

\section{PCR Amplification}

RAPD- PCR technique was used to amplify the DNA by using six primers (OPE A-10, OPE G-14, U-17, OPE K-02, OPA-18 and M 32) as shown in table (1). The PCR condition include an initial denaturation at $94^{\circ} \mathrm{C}$ for 1.5 minute, then 45 cycle of denaturation at $94^{\circ} \mathrm{C}$ for $1 \mathrm{~min}$., Annealing at $36^{\circ} \mathrm{C}$ for $1 \mathrm{~min}$., extension at $72^{\circ} \mathrm{C}$ for $2 \mathrm{~min}$. Then one cycle of final extension at $72^{\circ} \mathrm{C}$ for $7 \mathrm{~min}$.

Table (1): Six primers (OPE A-10, OPE G-14, U-17, OPE K-02, OPA-18 and M 32) were used in the current study.

\begin{tabular}{lc}
\hline $\begin{array}{l}\text { Primer } \\
\text { sequences 5' to 3' }\end{array}$ & Molecular Primers \\
\hline GGATGAGACC & OPE G-14 \\
GTGATCGCAC & OPE A-10 \\
GTCTCCGCAA & OPE K-02 \\
CTGCCAGCAT & U-17 \\
CTGCCAGCAT & M 32 \\
\hline
\end{tabular}

\section{DNA Electrophoresis}

Electrophoresis $(100 \mathrm{~V})$ was carried out for 30 minutes to separate amplified products in agarose gels $(1.5 \%)$ and then stained by ethidium bromide. A photographic record was acquired under UV-illumination.

\section{Data analysis}

Only unblemished and repeatable application products were recorded as 0 for absent bands and 1 for the ones that were present. The precise bands suitable for ascertaining genotype and species were first named with a primer number, and then the rough size of the amplified fragment in base pairs. Analysis of the amplified products was done through 
pairwise comparison of the genotypes on the basis of the proportion of common fragments, and a similarity matrix was computed (Nei \& $\mathrm{Li}$, 1979). The 0 or 1 data matrix was generated and utilised for computing the genetic distance and similarity by utilising 'Simqual', an NTSYS-PC subprogram (numerical taxonomy-and multivariate analysis system program) (Rohlf, 2000). With regards to the genetic distance matrix, construction of a dendrogram was done by making use of an unweight pair group method with arithmetic mean (UPGMA) cluster analysis that employed Molecular Evolutionary Genetics Analysis (MEGA) version 2.0 (Erdogan-Orhan \& Kartal, 2011).

ParARF3 gene expression for five apricot genotypes under marine algae extract treatments

Two concentrations of marine algae extract ( 5 and $10 \mathrm{ml} . \mathrm{L}^{-1}$ ) were used for apricot genotypes, and the results were ParARF3 gene expression amongst apricot in genotypes were kept in Marine Alga (Enteromorpha intestinalis + Cladophoropsis gerloffii) Extracts treatments 50 and $100 \mathrm{ml} . \mathrm{L}^{-1}$ for the five apricot genotypes (Kaisy, Labeeb-1, Zinni, Baia, and Zagheni).

\section{Gene expression measurement}

cDNA synthesis and total RNA extraction: Total RNA was isolated from samples of various treatment leaves based on uses (Total RNA Isolation kit, Bioneer, South Korea). The RNA quality was confirmed based on the intact ribosomal bands seen, followed by agarose gel electrophoresis. The DNase I Mix/ BioneerlKorea (DNase I, $\mathrm{MnCl}_{2}$, yellow core buffer) was used to remove DNA from RNA samples. The cDNA Syntheses kit, Bioneer, South Korea) with Oligo (dT) 15 primer was employed to synthesise first strand cDNA from $16 \mu \mathrm{l}$ of total RNA, followed by the manufacturer's instructions, and gel electrophoresis was employed for quantification.

\section{Quantitative Real Time PCR (qRTPCR):}

qRT-PCR employing a Mini Option's System real-time PCR as well as GO Taq Master Mix-SYBR Green kit QPCR/ Bioneer ISouth Korea were used for gene expression analyses. To produce a product of $1113 \mathrm{bp}$, primers were designed for gene specific amplification pertaining to RNA apricot genotypes, and these primers are available in Gen Bank (www.ncbi.nih.nlm.gov/Gen Bank/EMBL/DDBJ) - the primers sequences ParARF3 gene (Auxin response factor 3). There were two parts to the primers for QRTPCR amplification (Forward 5CTGAACAGTGCAACGGAGGA-3) (Reverse5-AACAACGCGAAGAGGT-3), T.m (59.75-59.89), GC \%55. In plate, PCR reactions were conducted in duplicate. Reaction mix $(22.5 \mu 1$ per well) included $2.5 \mu 1$ forward and reverse primers, $12.5 \mu 1$ Master Mix SYBR Green, $2.5 \mu 1$ of cDNA and $7.5 \mu 1$ DEPC-D.W. The thermal cycling scenarios comprised an initial denaturation stage of $95^{\circ} \mathrm{C}$ for $10 \mathrm{~min}$, followed by 40 cycles of $95^{\circ} \mathrm{C}$ for $30 \mathrm{~s}, 60^{\circ} \mathrm{C}$ for $1 \mathrm{~min}$, and $72^{\circ} \mathrm{C}$ for $30 \mathrm{~s}$. The melting curve analysis was employed to monitor the specificity of the PCR amplification and in the final step. To normalise, housekeeping Pa26sRIP gene (Pa26sRIP Genebank accession no. AFOO3997) was employed as endogenous reference (Forward5AACGCAGGTGTCCTAAGATGAG-3) (Reverse 5-GCTGCCACAA GCCAGTTA TCC-3), T.m(60.04-59.82), GC \%55. The real-time PCR data was analysed using GeneX programs. 


\section{Results \& Discussion}

Fig. (1) demonstrated the results pertaining to isolate total DNA from the leaves of the studied apricot genotypes, which were filtered and then transferred to agar gel $(1.5 \%)$, at voltage $100 \mathrm{~V}$ for $30 \mathrm{~min}$, in order to isolate the DNA from this apricot.

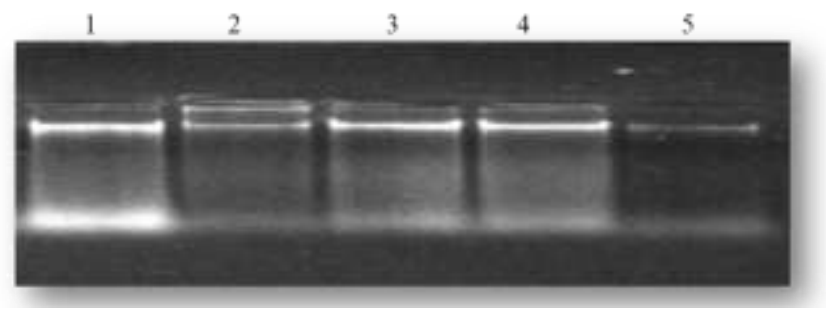

Fig. (1): Represents the isolated total DNA quality extracted of the apricot genotypes [1; Kaisy, 2; Labeeb-1, 3; Zinni; 4; Baia, and 5; Zagheni] on agarose gel (1.5\%) and voltage 100 $\mathrm{V}$ for 30 minutes

Polymorphisms and monomorphisms detected byof polymorphism and this attribute has been RAPAD-Markers considered in the current work (Fig. 2).

One of the major and significant attributes of the RAPD method is identifying high degrees
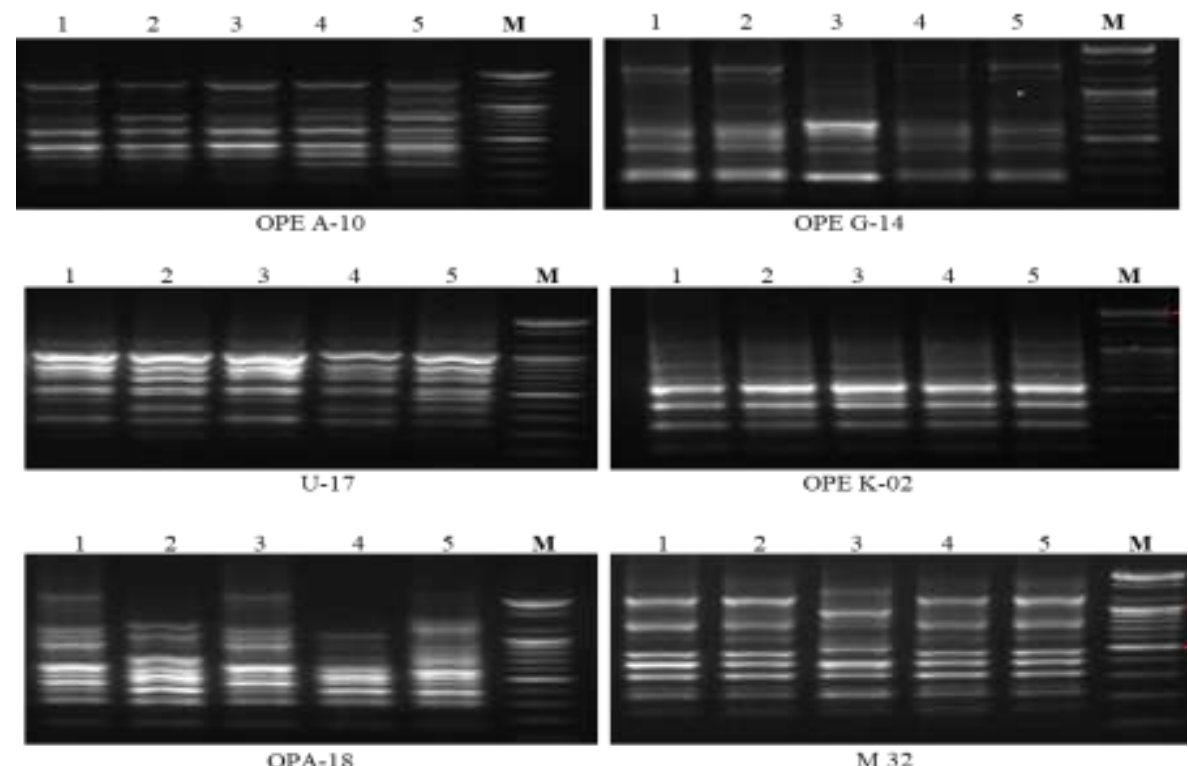

Fig. (2): RAPD profiles of the five apricot genotypes amplified with Molecular Markers, (M; molecular weight marker), apricot genotypes: (1; Kaisy, 2; Labeeb-1, 3; Zinni; 4; Baia, and 5; Zagheni) on agarose gel (1.5\%) and voltage (100V)

for

30

minute. 
Table (2): Number of amplicons, polymorphic, monomorphic amplicons, and percentage of monomorphism, polymorphism as revealed by Molecular markers among the five apricot genotypes.

\begin{tabular}{|c|c|c|c|c|c|c|c|c|}
\hline $\begin{array}{l}\text { Molecular } \\
\text { Primers }\end{array}$ & $\begin{array}{l}\text { Primer (RAPD) } \\
\text { sequences 5' to 3' }\end{array}$ & $\begin{array}{c}\text { No. of } \\
\text { total } \\
\text { amplified } \\
\text { fragments }\end{array}$ & $\begin{array}{c}\text { No. of } \\
\text { Unique } \\
\text { Fragments } \\
\text { Bands }\end{array}$ & $\begin{array}{c}\text { Unique } \\
\text { Fragments } \\
\text { Bands } \\
\text { Percentage } \\
(\%)\end{array}$ & $\begin{array}{c}\text { No. of } \\
\text { Polymorphic } \\
\text { Fragments } \\
\text { Bands }\end{array}$ & $\begin{array}{l}\text { Polymorphism } \\
\text { Fragments } \\
\text { Percentage }(\%)\end{array}$ & $\begin{array}{c}\text { No. of } \\
\text { Monomorphic } \\
\text { Fragments } \\
\text { Bands }\end{array}$ & $\begin{array}{c}\text { Monomorphic } \\
\text { Fragments } \\
\text { Percentage } \\
(\%)\end{array}$ \\
\hline OPE G-14 & GGATGAGACC & 9 & 1 & 11.11 & 3 & 33.33 & 5 & 55.55 \\
\hline OPE A-10 & GTGATCGCAC & 13 & 1 & 7.69 & 3. & 23.07 & 9 & 69.23 \\
\hline 0PE K-02 & GTCTCCGCAA & 14 & 3 & 21.42 & 3 & 21.42 & 8 & 57.14 \\
\hline OPA-18 & AGGTGACCG T & 16 & 3 & 18.75 & 3 & 18.75 & 9 & 56.25 \\
\hline & Total & 80 & 14 & & 17 & & 47 & \\
\hline \multicolumn{2}{|c|}{ Average } & 13.33 & 2.33 & 17 & 2.83 & 22.16 & 7.83 & 59.64 \\
\hline
\end{tabular}


Investigation of seven primers was done with the DNA of the five apricot genotypes. Of the seven tested primers, six produced easily storable and reproducible RAPD profiles with several amplified DNAfragments ranging from 9 to 16 (table 2). Primer OPN-16 returned negative results. The overall quantity of fragments generated by the six primers was 80 at an average of 13.33 fragments/primer. As demonstrated in table (2), primer OPA-

\section{Apricot genotypes fragment numbers from RAPD markers}

On comparing the apricot genotypes, RAPDmarker data demonstrated that high fragment number was seen in Zaghenia genotype, reaching to 68 fragments band, while Baia genotype showed lesser fragment number reaching to 60 fragments band (Table 3). 18 amplified the maximum number of amplicons to reach to 16 , while primer OPE G-14 allowed amplification of minimum number of fragments reaching to 9 . The number of unique fragments ranged from 1 to 3 at an average of 2.33 fragments/ primer. The highest unique percentage band depicted in U-17 touched $23 \%$. The overall quantity of polymorphic bands touched 17 at an average of 2.83 fragments/primer. The number of monomorphic lied in the range of 5 to 10 and was a total of monomorphic 47 with an average of 7.83 fragments/primer. The highest number of monomorphic bands was 10, acquired through primer M32.

Table (3): Apricot genotypes fragments numbers Molecular markers

\begin{tabular}{c|c}
\hline Genotype & No. of total fragment \\
\hline Zaghenia & 68 \\
Baia & 60 \\
Zinni & 65 \\
Labeeb & 62 \\
Kaisy & 62 \\
\hline
\end{tabular}

\section{Genetic distance among apricot genotypes}

Data pertaining to RAPD markers included 5 apricot genotypes containing reproducible primers that were employed for genetic distance as well as similarity value coefficient. Between Zaghenia and Zinni, a maximum genetic distance value was seen reaching 0.8 along with less similarity value reaching 20\%. While between Kaisy and Baia, a minimum genetic distance value was seen reaching 0.44721 along with high similarity value reaching $55.3 \%$ (Table 4 ). 
Al-Janabi1 and Alhasnawi / Basrah J. Agric. Sci., 34(2): 60-74, 2021

Table (4): Genetic distance among apricot genotypes.

\begin{tabular}{cccccc}
\hline Genotypes & Kaisy & Labeeb-1 & Zinni & Baia & Zaghenia \\
\hline Zaghenia & 0.52915 & 0.6 & 0.8 & 0.56569 & 0 \\
Baia & 0.44721 & 0.52915 & 0.74833 & 0 & 0.56569 \\
Zinni & 0.72111 & 0.7746 & 0 & 0.74833 & 0.8 \\
Labeeb-1 & 0.4899 & 0 & 0.7746 & 0.52915 & 0.6 \\
Kaisy & 0 & 0.4899 & 0.72111 & 0.44721 & 0.52915 \\
\hline
\end{tabular}

Genetic relationships as revealed by RAPD markers and using dendrograms

For ascertaining the genetic relationships between five apricot genotypes, the scoring data were utilised to calculate the similarity matrices. For the cluster analysis, these genetic similarity matrices were employed to construct a dendrogram used for cluster analysis and UPGMA.analysis. According to the cluster tree analysis (Fig. 3), the genotypes were generally split into two core groups A and B. Zinni is also a group that included one apricot genotype, whose genetic similarity reached $20 \%$ when compared with the other genotypes in B group. The [B group] was split into two sub-clusters B1 and B2 with genetic similarity touching $44 \%$. The first sub-cluster [B1] comprised just Labeeb-1 genotype. The second sub-cluster [B2] was split into two sets [B2A and $\mathrm{B} 2 \mathrm{~B}]$. The first set [B2A] comprised Kaisi and Baia genotypes with high genetic similarity touching 52\%, and the second set [B2B] comprised only Zaghinia genotype.

As per fig. (4), success pertaining to RNA extraction from apricot genotypes leaves, which were introduced to Marine Alga Extracts treatments, by employing SV Total RNA Isolation kit/ Bioneer-South Korea, was seen to be highly efficient and yielded RNA concentration in the range of 72 to 79 (ng. $\mu \mathrm{l}^{-}$ ${ }^{1}$ ) with purity reaching 1.8 to 2 (OD260/280). The synthesised cDNA for RNA of apricot genotypes exposed to Marine Alga Extracts treatments was a success due to the use of cDNA syntheses kit/ Bioneer - South Korea that was specific as well as highly efficient (Fig. 5). 


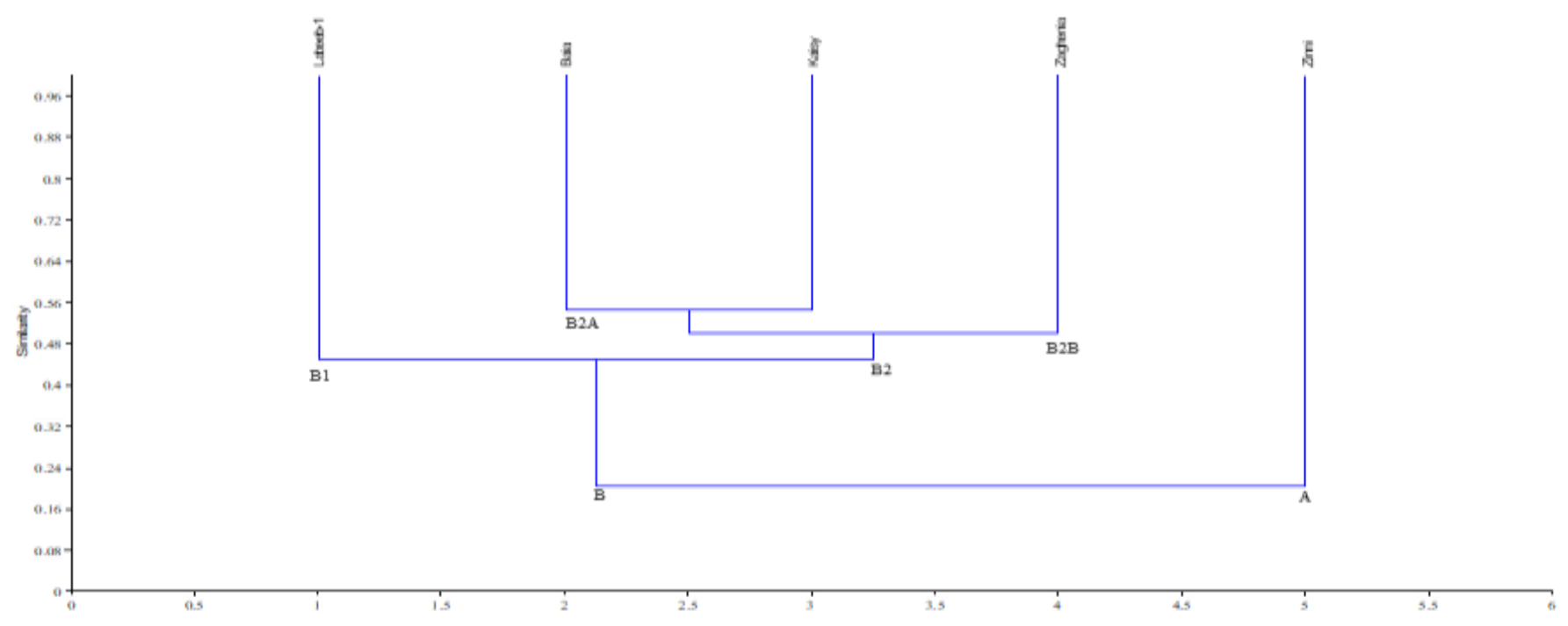

Fig. (3): Dendrogram for the five apricot genotypes (1; Kaisy, 2; Labeeb-1, 3; Zinni; 4; Baia, and 5; Zagheni) constructed from RAPDs-data using UPGMA (Unweighted Pair-group Arithmetic Average) and similarity matrices computed according to treatments

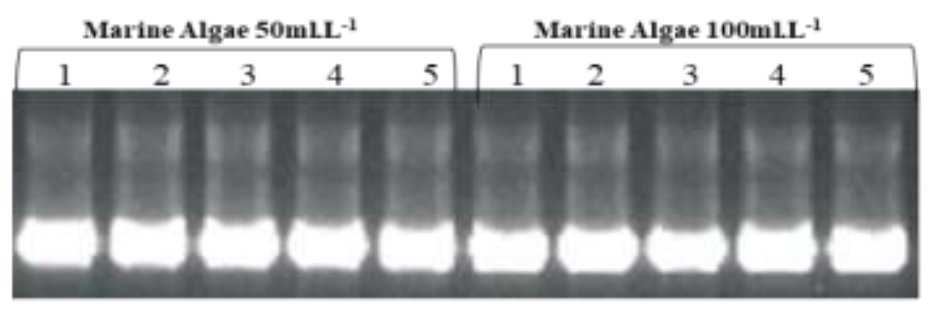

Fig. (4): Represents extraction total RNA of the apricot genotypes (1; Kaisy, 2; Labeeb-1, 3; Zinni; 4; Baia, and 5; Zagheni) under 50 and 100 ml.L-1 of marine alga extracts treatments on agarose gel $(1.5 \%)$ and voltage $(100 \mathrm{~V})$ for $20 \mathrm{~min}$

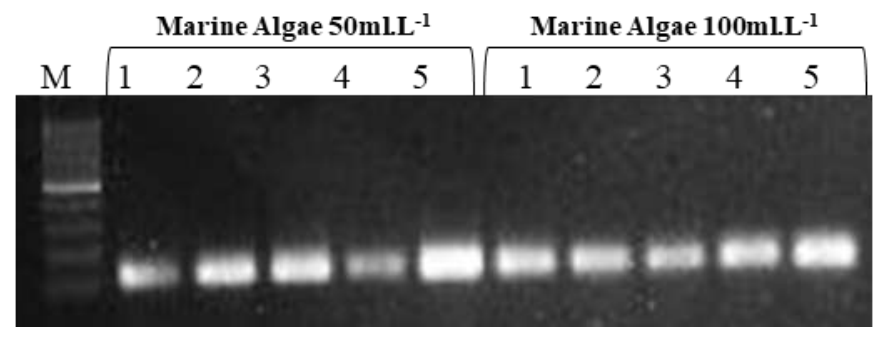

Fig. (5): Synthesis cDNA for RNA of the apricot genotypes (1; Kaisy, 2; Labeeb-1, 3; Zinni; 4; Baia, and 5; Zagheni) under 50 and $100 \mathrm{ml} . \mathrm{L}-1$ of marine alga extracts treatments on agarose gel $(1.5 \%)$ and voltage $(100 \mathrm{~V})$ for $20 \mathrm{~min}$. 
The ParARF3 gene that is responsible for Auxin response factor 3 plays a key role in the synthesis of auxin. The expression ParARF3 gene patterns in genotypes were kept in marine Alga Extracts treatments 50 and $100 \mathrm{ml} . \mathrm{L}^{-1}$ and were seen to be amongst apricot genotypes. For both marine alga extracts 50 and $100 \mathrm{ml} . \mathrm{L}^{-1}$, the high relative gene expression was seen to appear in Zaghenia genotype, which reached 38.55 and 48.54-fold, respectively. The ParARF3 relative gene expression pertaining to Zinni genotypes was second as well as convergent with that of gene expression for Zaghenia genotype results, which were seen to reach 36.10 and 44.13-fold, respectively. In ParARF3 relative gene expression, Labeeb-1 genotype was found to be the lowest, which was exposed to marine Alga Extracts treatments 50 and $100 \mathrm{ml} . \mathrm{L}^{-1}$ and reached 18.01 and 30.1-fold, respectively. The results from Baia and Kaisy genotypes lied in between the lowest and highest ParARF3 value gene expression exposed to marine alga Extracts treatments 50 and $100 \mathrm{ml} . \mathrm{L}^{-1}$ that reached 22.12, 26.13 and 31.38, 36.39-fold, respectively (Fig. 6).

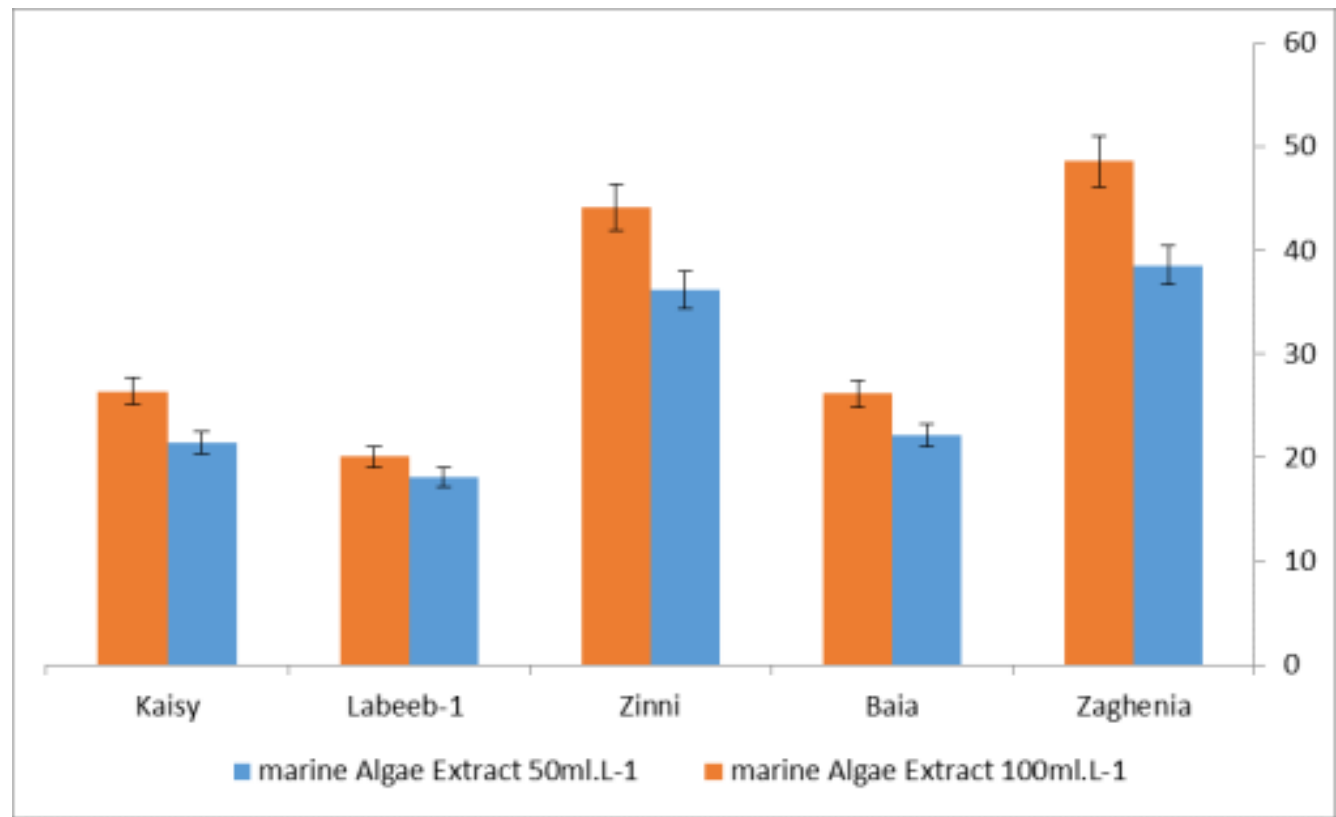

Fig. (6): The expression ParARF3 gene patterns in genotypes were kept in marine alga extracts treatments 50 and $100 \mathrm{ml}^{-\mathrm{L}^{-1}}$ for the five apricot genotypes (1; Kaisy, 2; Labeeb-1, 3; Zinni; 4; Baia, and 5; Zagheni).

\section{Discussion}

The RAPD method has been extensively utilised in research on wild plants (Brakea et al., 2014; Rao et al., 2020; Sirijan et al., 2020). According to the observations, a high genetic distance was noted between Zaghenia and Zinni genotypes and a low genetic distance between Kaisy and Baia, with high similarity. This genetic data could be utilised for instituting family trees and the genetic distance to common descendants (Morales et al., 2011).

This study offers a constructive tool for the genetic characterisation of apricots Baia and Kaisy, typical yields stemming from centuries of selection. The molecular markers signify a valuable tool to certify genuineness and traceability in the agri-food chain for 
ascertaining production of every variety and for regulating the compliance of plant material during the different nursery phases.

RAPD markers have been already successfully employed for differentiation at a molecular level for apricot genotypes (Shangguan et al., 2012). The RAPD profile only discloses the screening of a very tiny portion of the entire plant genome. Therefore, corroboration of the generated RAPD profile is essential and this could be achieved by utilising various molecular marker systems (Khor et al., 2020). These outcomes might signify the ability of the studied molecular method to distinguish among the apricot genotypes, quite beneficial in choosing the parental genotypes utilised in hybridisation breeding programs. Furthermore, the RAPD markers, by effectively distinguishing between apricot genotypes, could be utilised for diversity and characterisation study of apricot's genetic resources.

By identifying various key auxin biosynthetic genes, auxin biosynthesis can be monitored by analysing changes in gene expression in response to different signals or in various mutant backgrounds (Zhao, 2010). The adaptations of gene expression driven by tissue or cell-specific promoters using gene editing technology or classic genetic methods and the key genes involved in auxin biosynthesis might be directly regulated by transcription factors (Cao et al., 2020).

\section{Conclusion}

The ParARF3 gene that is responsible for Auxin response Factor 3 pattern was found to be the same for RAPD marker and, amongst genotypes, genetic similarity was highest between Zaghenia and Zinni apricot genotypes. As per the results, ParARF3 gene is responsible for Auxin response factor 3, which showed lowest genetics similarity amongst Leebeb-1 genotype as well as others too. The results were the same even for RAPD marker. Thus, it could be that the Zaghenia and Zinni genotypes grew up together exposed to semi-conditions, while the other genotypes grew up exposed to different conditions as well as adaptation pertaining to that conditions. Comprehension of genetic diversity in apricots is vital for planning and usage of breeding programs, germplasm collection and conducting of molecular research.

\section{Conflict of interest}

Authors declare that there is no conflict of interests.

\section{Orcids}
A.A. AL-Janabi: https://orcid.org/0000- 0002-7644-0809

\section{A.N. Alhasnawi:}

https://orcid.org/0000-0003-2817-8807

\section{References}

Abd El-Moniem, E. A. \& Abd-Allah, A. S. E. (2008). Effect of green alga cells extract as foliar spray on vegetative growth yield and berries quality of superior grapevines. American-Eurasian Journal of Agricultural \& Environmental Sciences, 4, 427433. http://www.idosi.org/aejaes/jaes4(4)/5.pdf

Alhasnawi, A. N. (2019). $\quad \beta$-Glucan-Mediated Alleviation of $\mathrm{NaCl}$ Stress in Ocimum basilicum L. in Relation to the Response of Antioxidant Enzymes and Assessment DNA Marker. Journal of Ecological Engineering, 20, 90-99. https://doi.org/10.12911/22998993/110790

Alhasnawi, A. N., Kadhimi, A. A., Isahak, A., Mohamad, A., Ashraf, M. F., Doni, F., Yusoff, W. M., \& Che Radziah, Z. (2017). DNA Isolation and Optimization of ISSR-PCR Reaction System in Oryza sativa L. International Journal on Advanced Science, Engineering and Information $\begin{array}{llll}\text { Technology. } & 7, & 2264-\end{array}$ 


\section{Al-Janabi1 and Alhasnawi / Basrah J. Agric. Sci., 34(2): 60-74, 2021}

http://insightsociety.org/ojaseit/index.php/ijaseit/ar ticle/view/1621

Al Khazraji, H. A. K., Abd, A. M., \& Abdulla, A. A. (2021). The determination of the genetic distance of various snake melon Cucumis melo var. flexuosus cultivars using inter simple sequence repeat technique (ISSR). Basrah Journal of Agricultural Sciences 34, 111-123. https://doi.org/10.37077/25200860.2021.34.1.10

Barakat, M. N, El-Sabagh, A. S, Etman, A. A., \& Genaidy, E. A. A. (2012). Genetic analysis of some apricot c.v canino genotypes using RAPDPCR technique as a major molecular marker of genetic differentiation among apricot clones. American-Eurasian Journal of Agricultural \& Environmental Sciences, 12, 139-143. https://www.idosi.org/aejaes/jaes12(2)12/1.pdf

Bhadkaria, A., Gupta, N., Narvekar, D. T., Bhadkariya, R., Saral, A., Srivastava, N., Koul, K. K., \& Bhagyawant, S. S. (2020). ISSR-PCR approach as a means of studying genetic variation in moth bean (Vigna aconitifolia (Jacq.) Maréchal). Biocatalysis and Agricultural Biotechnology, 30, 101827. https://doi.org/10.1016/j.bcab.2020.101827.

Brakea, M., Migdadi, H., Al-Gharaibeh, M., Ayoub, S., Haddad, N., \& El Oqlah, A. (2014). Characterization of Jordanian olive cultivars (Olea europaea L.) using RAPD and ISSR molecular markers. Scientia Horticulturae, 176, 282-289. http://dx.doi.org/10.1016/j.scienta.2014.07.012

Cao, J., Li, G., Qu, D., Li, X. \& Wang, Y. (2020). Into the seed: auxin controls seed development and grain yield. International Journal of Molecular Sciences, $\quad 21, \quad 1662$. https://doi:10.3390/ijms21051662

Chiou, C. Y., Shih, H. C., Tsai, C. C., Jin, X. L., Ko, Y. Z., Mantiquilla, J. A., Weng I., \& Chiang, Y. C. (2020). The genetic relationships of Indian jujube (Ziziphus mauritiana Lam.) cultivars using SSR markers. Heliyon, 6, e05078. https://doi.org/10.1016/j.heliyon.2020.e05078.

Cmejlova, J., Rejlova, M., Paprstein, F., \& Cmejla, R. (2020). A new one-tube reaction kit for the SSR genotyping of apple (Malus domestica Borkh.).
Plant Science, 110768.

https://doi.org/10.1016/j.plantsci.2020.110768.

Erdogan-Orhan, I., \& Kartal, M. (2011). Insights into research on phytochemistry and biological activities of Prunus armeniaca L. (apricot). Food Research International, 44, 1238-1243. https://doi.org/10.1016/j.foodres.2010.11.014

Guerriero, R., \& Watkins, R. (1984). Revised descriptor list for apricot (Prunus armeniaca). IBPGR Secretariat, Rome, CEC Secretariat, Brüssels. $\quad 36 \quad$ pp. https://www.bioversityinternational.org/fileadmin/ user_upload/Descriptors_apricot.pdf

Iannelli, D., Cottone, C., Viscardi, M., D’Apice, L., Capparelli, R., \& Borselli, M. (1998). Identification of lemon by flow cytometry and RAPD markers. International Journal of Plant Science, $\quad 159, \quad 864-869$. https://doi.org/10.1086/297608

Kalapchieva, S., Kosev, V., \& Vasileva, V. (2020). Genetic and phenotypic assessment of garden peas (Pisum sativum L.) genotypes. Basrah Journal of Agricultural Sciences, 33, 107-121. https://doi.org/10.37077/25200860.2020.33.1.09

Khor, S. P., Yeow, L. C., Poobathy, R., Zakaria, R., Chew, P. L., \& Subramaniam, S. (2020). Dropletvitrification of Aranda Broga Blue orchid: Role of ascorbic acid on the antioxidant system and genetic fidelity assessments via RAPD and SCoT markers. Biotechnology Reports 26, e00448. https://doi.org/10.1016/j.btre.2020.e00448

Koller, B., Lehmann, A., McDermott, J. M., \& Gessler, C. (1993). Identification of apple cultivar using RAPD markers. Theoretical and Applied Genetics 85, 901-904. https://doi.org/10.1007/BF00225036

Krichen, L., Mnejja, A., Aru, P., Marrakchi, M., \& Trifi-Farah, N. (2006) Use of microsatellite polymorphisms to develop an identification key for Tunisian apricots. Genetic Resources and Crop Evolution, 53, 1699-1706. https://doi.org/10.1007/s10722-005-1220-1

Kumar, S., Tamura, K., Jakobsen, I. B., \& Nei, M. (2001). MEGA2: Molecular evolutionary genetics 
analysis software. Bioinformatics 17, 1244-1245. https://doi.org/10.1093/bioinformatics/17.12.1244

Layne, R. E. C., Bailey, C. H., \& Hough, L. F. (1996). Apricots: 79-111. In Janick, J. \& Moore, J. M. (Editors). Fruit Breeding, Vol. 1: Tree and Tropical Fruits, John Willey and Sons, New York. 632pp. https://www.wiley.com/enus/Fruit+Breeding\%2C+Volume+1\%2C+Tree+an d+Tropical+Fruits-p-9780471310143

Liu, J., Deng, J. L., \& Tiana, Y. (2020). Transcriptome sequencing of the apricot (Prunus armeniaca L.) and identification of differentially expressed genes involved in drought stress. Phytochemistry, 171, 112226.

https://doi.org/10.1016/j.phytochem.2019.112226

Maghuly, F., Borroto F. E., Ruthner, S., Pedryc, A., \& Laimer, M. (2005). Microsatellite variability in apricot (Prunus armeniaca) reflects their geographical origin and breeding history. Tree Genetics \& Genomes, 1, 151-165. https://doi.org/10.1007/s11295-005-0018-9

Mariniello, L., Sommella, M. G., Sorrentino, A., Forlani, M., \& Porta R. (2002). Identification of Prunus armeniaca cultivar by RAPD and SCAR markers. Biotechnology Letters 24, 749-755. https://doi.org/10.1023/A:1015516712754

Morales, R. G. F., Resende, J. T. V., Faria, M. V., Andrade, M. C., Resende, L. V., Delatorre, C. A., \& Silva, P. R. (2011). Genetic similarity among strawberry cultivars assessed by RAPD and ISSR markers. Scientia Agricola, 68, 665-670. https://doi.org/10.1590/S0103-0162011000600010

Nei, M., \& Li, W. H. (1979). Mathematical model for studying genetic variation in terms of restriction endonucleases. Proceeding of the National Academy of Sciences of the USA 76, 5269-5273. https://doi.org/10.1073/pnas.76.10.5269

Rao, G. K., Kapadia, C., Patel, N. B., Desaia, K. D., \& Murthy, P. N. N. (2020). Genetic diversity analysis of greater yam (Dioscorea alata L.) genotypes through RAPD and ISSR markers. Biocatalysis and Agricultural Biotechnology, 23, 101495.

https://doi.org/10.1016/j.bcab.2020.101495
Rohlf, F. J. (2000). NTSYS-pc: Numerical taxonomy and multivariate analysis system, Version 2.1. Exeter Software Setauket. New York. 42pp.

Romero, C., Prdryc, A., Munoz, V., Llacer, G., \& Badenes, M. L. (2003). Genetic diversity of different apricot geographical groups determined by SSR markers. Genome, 46, 244-252. https://doi.org/10.1139/g02-128

Rowland, L. J., \& Levi, A. (1994). RAPD-based genetic linkage map of blueberry derived from a cross between diploid species (Vaccinium darrowi and V. ellottii). Theoretical and Applied Genetics 87, 863-868. https://doi.org/10.1007/BF00221139

Shangguan, L., Wang, Y., Li, X., Wang, Y., Song, C., \& Fang J. (2012). Identification of selected apricot cultivars using RAPD and EST-SSR markers. International Journal of Cytology, Cytosystematics and Cytogenetics, 65, 130-139. https://doi.org/10.1080/00087114.2012.711668

Sirijan, M., Drapal, M., Chaiprasart, P., \& Fraser, P. D. (2020). Characterisation of Thai strawberry (Fragaria ananassa Duch.) cultivars with RAPD markers and metabolite profiling techniques. Phytochemistry, $\quad 180, \quad 112522$. https://doi.org/10.1016/j.phytochem.2020.112522

Spinelli, F., Giovanni, F., Massimo, N., Mattia, S., \& Guglielmo, C. (2009). Perspectives on the use of a sea weed extract to moderate the negative effects of alternate bearing in apple trees. Journal of Horticultural Science and Biotechnology 17, 131137.

https://doi.org/10.1080/14620316.2009.11512610

Uzuni, A., Osman, G., Ubeyit, S., Mustafa, B., Kadir ,U., \& Yilmaz, K. U. (2010). SRAP based genetic analysis of some apricot cultivars. Romanian Biotechnological Letters, 15, 5396- 5404. https://e-repository.org/rbl/vol.15/iss.4/5.pdf

Volkova, P. A., Bog, M., Zablocka, B., \& Oberprieler, C. (2020). Elevation does not matter? Genome screening using AFLP fails to reveal selection along elevational transects: a case study of Caucasian Primula vulgaris Huds. (Primulaceae). Flora,

151726. https://doi.org/10.1016/j.flora.2020.151726. 
Wang, X., Li, L., Zhao, J., Li, F., Guo W., \& Chen X. (2017). Effects of different preservation methods on inter simple sequence repeat (ISSR) and random amplified polymorphic DNA (RAPD) molecular markers in botanic samples. Comptes Rendus Biologies, 340, 204-213. https://doi.org/10.1016/j.crvi.2017.03.002

Welsh, J., Peterson, C., \& McClelland, M. (1991). Polymorphisms generated by arbitrarily primed PCR in the mouse: application to strain identification and genetic mapping. Nucleic Acids Research, 19, 303-306. https://doi.org/10.1093/nar/19.2.303

Williams, J. G. K., Kubelik, A. R., Livak, K. J., Rafalski, J. A., \& Tingey, S. V. (1990). DNA polymorphism amplified by arbitrary primers are useful as genetic markers. Nucleic Acids Research, 18 , 6531-6535. https://doi.org/10.1093/nar/18.22.6531

Xiang, L., Li, X. L., Wang, X. S., Yang, J., Lv, K., Xiong, Z. Q., Chen, F. Q., \& Huang, C. M. (2020). Genetic diversity and population structure of Distylium chinense revealed by ISSR and SRAP analysis in the Three Gorges Reservoir Region of the Yangtze River, China. Global Ecology and Conservation, 21, e00805. https://doi.org/10.1016/j.gecco.2019.e00805.
Yilmaz, K. U., \& Paydas-Kargi, S. (2012). A new morphological trait for apricot characteristics. Acta Horticulturae $\quad 862, \quad 83-84$. https://doi.org/10.17660/ActaHortic.2010.862.11

Yuan, Z., Chen, X., He, T., Feng, J., Feng, T., \& Zhang C. (2007). Population genetic structure in apricot (Prunus armeniaca L.) cultivars revealed by fluorescen-AFLP markers in Southern Xinjiang, China. Journal of Genetics and Genomics, 37, 1037-1047. https://doi.org/10.1016/S16738527(07)60117-9

Zhang, X., \& Schmidt, R. E. (1999). Biostimulating turfgrasses. Ground Naintenance 34, 14-32.

https://scholar.google.com/scholar_lookup?author=X.+ Zhang\&author=R.+Schmidt+\&publication_year $=1$ 999\& title=Biostimulating+turfgrasses $\&$ journal $=\mathrm{Gr}$ ounds+Maintenance $\&$ volume $=34 \&$ pages $=14-15$

Zhao, Y. (2010). Auxin biosynthesis and its role in plant development. Annual Review of Plant Biology, 2, 49-64. https:// doi.org/10.1146/annurev-arplant-042809-112308 


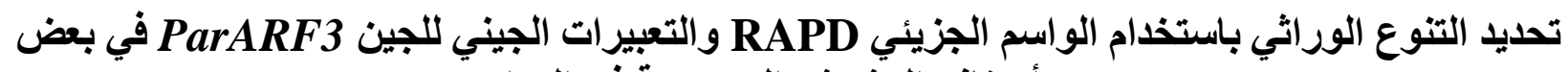 أصناف المشمش المزروعة في العراق}

\section{علي سعيد عطية الجنابي 1 و ارشد ناجي الحسناوي 2}

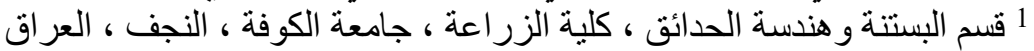

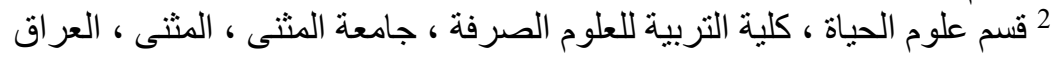

المستخلص: تم في هذه التجربة استخدام تقنية الواسمات الجزيئية بطريتنين الاولى هي تقنية الواسم الجزيئي لا DNA والتقنية

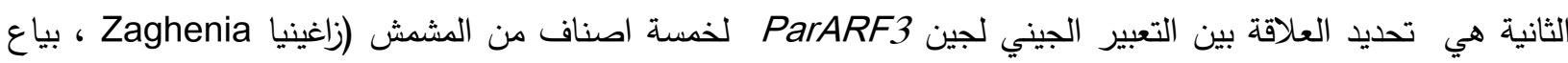

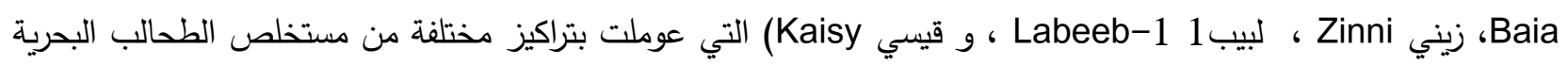

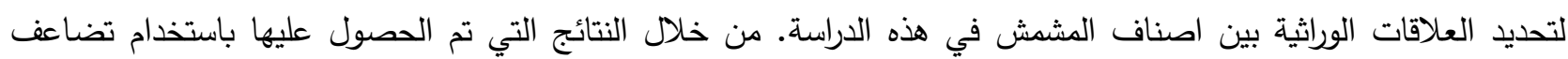

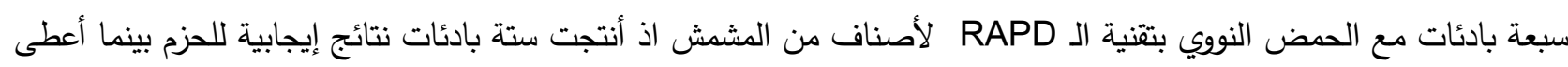
الباديء OPN-16 نتائج سلبية. العدد الإجمالي للحزم للبادئات الستة كان

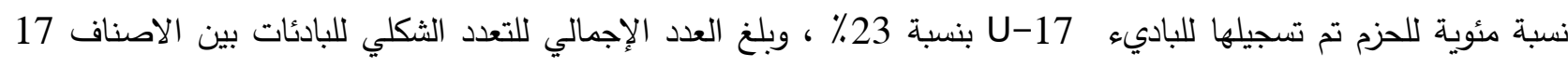

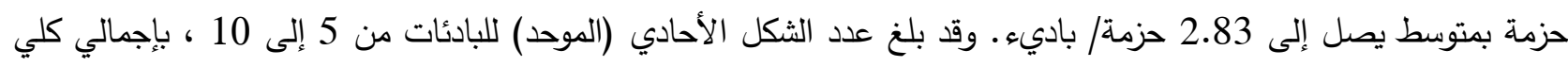

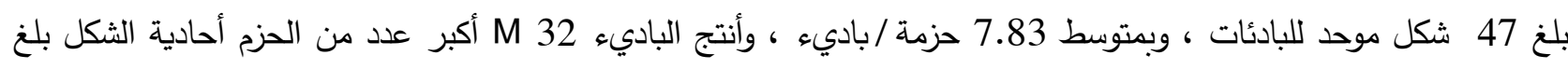
10 حزمة. ولوحظ اعلى بعد وراثي بين الصنف Zaghenia و ل

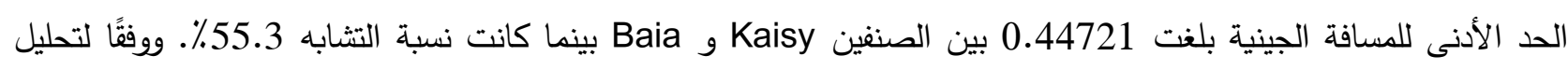

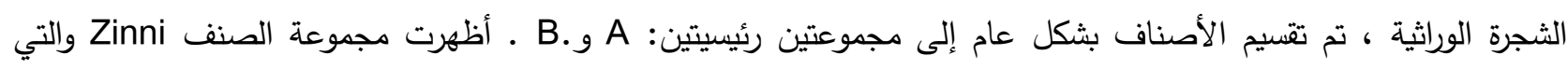

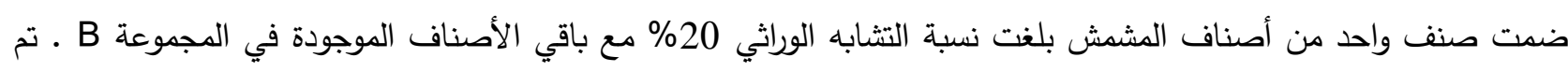
تقسيم المجموعة B إلى مجموعتين فرعيتين B1 و B2 وكان نسبة التشابه الوراثي 44 \% م. أظهرت هذه النتائج أن استخدام

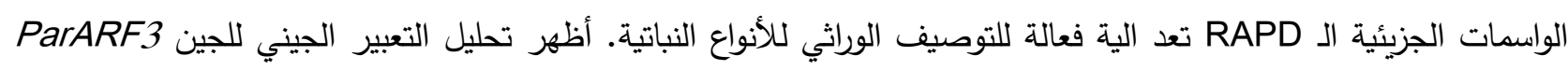
المقاس بأصناف المشمش الخمسة عند معاملتها بتراكيزين من مستخلص الطحالب البحرية. وقد بينت نتائج التعبير الجيني

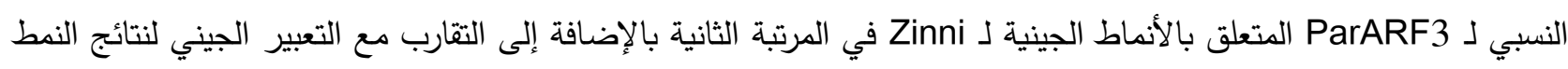
الوراثي لـ . Zaghenia تندرج الأنماط الجينية Kaia و Kaisy بين أدنى وأعلى تعبير جيني لقيمة البحرية. أظهرت هذه النتائج أن علامات RAPD تقدم بديلاً فعالاً للتوصيف الجيني للأنواع النباتية. الكلمات المفتاحية: النبات، DNA ، علامات RAPD، التنوع الجيني، التعبير الجيني 